\section{PENGARUH VERIFIKASI DATA NASABAH KREDIT UMKM DAN NILAI JAMINAN YANG DIBERIKAN UNTUK MENGHINDARI KREDIT BERMASALAH}

\author{
Christophorus Angga W \& Harry Roestiono \\ Program Studi Keuangan, Institut Bisnis dan Informatika Kesatuan \\ Bogor, Indonesia \\ Email:lemlit@stiekesatuan.ac.id
}

Pengaruh

Verifikasi Data

Nasabah Kredit

UMKM dan

Nilai yang

Diberikan untuk

Menghindari

Kredit

Bermasalah

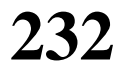

Variable used for this study consists of two variables independent that is Data Verification Influence of Micro, Small, and Medium Business Credit and Value Of Guarantees Provided with one variable dependent that is Avoid Problem Loans. Period of research conducted on quarterly financial statements from 2016-2017. Method used in this research is descriptive method.

This study intend to find out the effect of verifying the exact data and value of guarantee provided by the debtor capable to avoid problem loans in the future. The study results showed that consumers verification data and the type of guarantee able to make debtor avoid problem loans, it proven from decreased number of total problem loans during 2016 - 2017, although total credit still increase significant.

Keywords : Costumer Data Verification, Value of Guarantees, Avoid Problem Loans

\section{PENDAHULUAN}

Setiap usaha pasti akan berhadapan dengan risiko, begitu pula perbankan dalam menjalankan kegiatannya banyak melibatkan masyarakat, sehingga banyak pula risiko yang akan dihadapi. Risiko tidak harus selalu dihindari, sebab risiko dapat dikelola secara baik tanpa harus mengurangi hasil yang ingin dicapai. Perusahaan yang mampu mengelola risiko usahanya secara tepat diyakini dapat memberikan manfaat, sehingga tujuan perusahaan berupa target laba yang diharapkan dapat tercapai. Penelitian ini menguji pengaruh risiko pasar terhadap profitabilitas pada perbankan.

Bank Indonesia telah mengeluarkan peraturan mengenai penerapan Manajemen Risiko Bagi Bank Umum. Peraturan BI No. No.5/8/PBI/2003 berisi tentang bagaimana bank mengatur dan menerapkan manajemen risiko untuk meningkatkan efektivitas kinerja bank. Dengan diterapkannya manajemen risiko, maka perbankan diharapkan akan mampu mengidentifikasi risiko-risiko yang akan dihadapi, sehingga bank dapat mengelola risiko tersebut dengan baik.

Selain mengelola risiko dengan tepat, bank juga dituntut untuk meningkatkan efisiensi usahanya, diantarnya adalah perbandingan terbaik antara input dan output, antara keuntungan dengan biaya (antara hasil pelaksanaan dengan sumber yang digunakan), dimana perusahaan secara umum harus mampu memaksimalkan sumber yang dimiliki yang relatif terbatas untuk mendapatkan hasil yang optimal.

Dalam usaha bank memberikan kredit dikenal yang namanya risiko kredit atau dalam bahasa asing disebut credit risk. Credit risk adalah suatu potensi kerugian yang disebabkan oleh debitur karena tidak mampu membayar kewajiban utangnya baik utang pokok maupun bunga ataupun keduanya. Risiko kredit merupakan risiko yang paling signifikan dari semua risiko yang menyebabkan kerugian potensial. Risiko kredit dapat

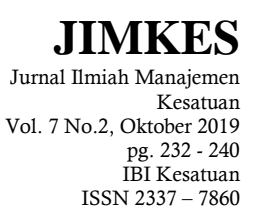


Pengaruh

Verifikasi Data

Nasabah

Kredit UMKM

dan Nilai yang

Diberikan

untuk

Menghindari

Kredit

Bermasalah

233 bersumber atau terjadi dari berbagai hal dan aktivitas bank, antara lain data nasabah yang diterima tidak akurat, jaminan yang diberikan nasabah palsu karena tidak dilakukan pengecekan ulang, pelanggaran pemberian kredit melebihi batas maksimum, serta aktivitas bank lainnya yang tercatat di dalam banking book maupun trading book. Karena pada faktanya, tidak semua kredit dapat dikembalikan secara sempurna dan tepat waktu artinya akan muncul suatu risiko kredit dan dapat terjadi pada setiap bank.

Untuk menghindari sesuatu yang tidak diinginkan, bank memiliki program pengawasan kredit yang bertujuan untuk menjaga, mencegah, mengamankan dan mengantisipasi terjadinya penyimpangan yang dapat menjadikan kredit bermasalah dan jika tidak ditindaklanjuti akan menyebabkan kerugian yang cukup besar untuk bank. Karena semakin besar jumlah kredit yang diberikan kepada debitur maka harus semakin ditingkatkan pengawasan dalam pemberian kredit untuk usaha maupun kebutuhan rumah tangga.

Ketika bank sudah mampu memetakan risiko-risiko yang akan dihadapi dan mampu mengelolanya dengan tepat, maka harapan untuk mendapatkan tingkat profitabilitas (laba) tertentu diyakini akan dapat tercapai.

\section{TINJAUAN PUSTAKA}

\section{Kredit}

Secara umum dan sederhana kredit berarti hutang (loan) dan hutang adalah sesuatu yang kelak harus dibayar kembali kepada yang telah meminjamkannya. Istilah kredit berasal dari bahasa latin "credere" ("credo" dan "creditum") yang berarti kepercayaan. Dapat dikatakan dalam hubungan ini bahwa kreditur (yang memberi kredit, lazimnya bank) dalam hubungan perkreditan dengan debitur (nasabah, penerima kredit) mempunyai kepercayaan, bahwa debitur dalam waktu dan dengan syarat-syarat yang telah disetujui bersama, dapat mengembalikan kredit yang bersangkutan (Rachmadi Usman, hlm. 236).

\section{Kredit UMKM}

Kredit UMKM adalah kredit kepada debitur usaha mikro, kecil dan menengah yang memenuhi definisi dan kriteria usaha mikro, kecil dan menengah sebagaimana diatur dalam UU No. 20 Tahun 2008 Tentang UMKM. Berdasarkan UU tersebut, UMKM adalah usaha produktif yang memenuhi kriteria usaha dengan dengan Batasan tertentu kekayaan bersih dan hasil penjualan tahunan.

\section{Jaminan Kredit}

Dalam memberikan kredit, bank harus melakukan analisis pemberian kredit yang memadai agar kredit yang diberikan oleh bank tidak berpotensi untuk menjadi macet (Rachmadi Usman, 2007 : 281). Kredit yang diberikan oleh bank mengandung resiko, sehingga dalam pelaksanaannya bank harus memperhatikan asas-asas perkreditan yang sehat (Hermansyah, 2013: 72). Muhammad Djumhana (2006,: 509510) mengatakan bahwa pemberian kredit bank wajib memperhatikan asas-asas pemberian perkreditan yang sehat, di antaranya:

1. Bank tidak diperkenankan memberikan kredit tanpa surat perjanjian tertulis.

2. Bank tidak diperkenankan memberikan kredit pada usaha yang sejak semula telah diperhitungkan kurang sehat dan akan membawa kerugian.

3. Bank tidak diperkenankan memberikan kredit untuk pembelian saham dan modal kerja dalam rangka kegiatan jual beli saham.

4. Bank tidak diperkenankan memberikan kredit melampaui batas maksimum pemberian kredit (legal lending limit). 
Untuk dapat melaksanakan kegiatan perkreditan secara sehat telah dikenal adanya prinsip 5C atau juga ada menyebutnya sebagai prinsip 6C (Teguh Pudjo Muljono, Hlm. 11), kelima prinsip yang klasik ini meliputi :

1. Character

Seperti telah diuraikan di awal dasar dari suatu pemberian kredit adalah atas dasar kepercayaan, jadi yang mendasari suatu kepercayaan itu adanya keyakinan dari pihak Bank bahwa si peminjam mempunyai moral, watak ataupun sifat-sifat pribadi yang positif dan kooperatif dan juga mempunyai rasa tanggung jawab baik dalam kehidupan pribadi sebagai manusia ataupun dalam menjalankan usahanya.

2. Capacity

Yang dimaksud capacity di sini yaitu suatu penilaian kepada calon debitur mengenai kemampuan melunasi kewajiban-kewajibannya dari kegiatan usaha yang dilakukannya atau kegiatan dari Bank.

3. Capital

Merupakan jumlah dana atau modal yang dimiliki sendiri oleh calon debitur.

4. Collateral

Collateral adalah barang-barang jaminan yang diserahkan oleh debitur sebagai jaminan atas kredit yang diterimanya.

5. Condition of Economy

Situasi dan kondisi politik, sosial, ekonomi, budaya dan lain-lain yang mempengaruhi keadaan perekonomian pada suatu saat maupun untuk suatu kurun waktu tertentu yang kemungkinannya akan dapat mempengaruhi kelancaran usaha dari perusahaan yag memperoleh kredit.

6. Constraint

Batasan-batasan atau hambatan yang tidak memungkinkan seseorang untuk melakukan bisnis di suatu tempat, walaupun prinsip 5C di atas memungkinkan atau cukup baik.

\section{Analisis Kredit}

Setiap permohonan kredit yang telah memenuhi syarat harus dilakukan analisis kredit secara tertulis, dengan prinsip sebagai berikut:

1. Bentuk, format, dan kedalaman analisis kredit ditetapkan oleh bank yang disesuaikan dengan jumlah dan jenis kredit.

2. Analisis kredit harus menggambarkan konsep hubungan total pemohon kredit, apabila pemohon telah mendapat fasilitas kredit dari bank atau dalam waktu bersamaan mengajukan permohonan kredit lainnya kepada bank.

3. Analisis kredit harus dibuat secara lengkap, akurat, dan objektif yang sekurangkurangnya meliputi hal-hal sebagai berikut:

a. Menggambarkan semua informasi yang berkaitan dengan usaha dan data pemohon termasuk hasil penelitian pada daftar kredit macet.

b. Penilaian atas kelayakan jumlah pemohon kredit dengan proyek atau kegiatan usaha yang akan dibiayai, dengan sasaran menghindari kemungkinan terjadinya praktek markup yang dapat merugikan bank.

c. Menyajikan penilaian yang objektif dan tidak dipengaruhi oleh pihak-pihak yang berkepentingan dengan pemohon kredit. Analisis kredit tidak boleh merupakan suatu formalitas yang dilakukan semata-mata untuk memenuhi prosedur perkreditan.

4. Analisis kredit sekurang-kurangnya harus mencakup penilaian 5C dan penilaian terhadap sumber pelunasan kredit yang dititikberatkan pada hasil usaha yang

\author{
Pengaruh \\ Verifikasi Data \\ Nasabah \\ Kredit UMKM \\ dan Nilai yang \\ Diberikan \\ untuk \\ Menghindari \\ Kredit \\ Bermasalah
}


Pengaruh

Verifikasi Data

Nasabah

Kredit UMKM

dan Nilai yang

Diberikan

untuk

Menghindari

Kredit

Bermasalah

235

dilakukan pemohon serta menyajikan evaluasi aspek yuridis perkreditan dengan tujuan untuk melindungi bank atas risiko yang mungkin timbul.

5. Dalam pemberian kredit sindikasi, analisis kredit bagi bank yang merupakan anggota sindikasi harus meliputi pula penilaian terhadap bank yang bertindak sebagai bank induk.

\section{METODE PENELITIAN}

Metode yang digunakan dalam penelitian ini adalah metode deskriptif. Metode ini merupakan suatu metode yang digunakan dengan cara mencari data yang dapat memberikan gambaran yang jelas tentang suatu kondisi kegiatan bank yang berhubungan dengan data nasabah kredit UMKM dan nilai jaminan yang diberikan untuk menghindari kredit bermasalah .

Penelitian ini mendeskripsikan bagaimana pengaruh verifikasi data dengan menggunakan prinsip 5C (character, capacity, capital, collateral, dan condition of economy) dan juga ingin melihat pengaruh nilai jaminan terhadap upaya menghindari kredit bermasalah.

\section{HASIL DAN PEMBAHASAN}

\section{Pembahasan}

\section{A. Verifikasi Data Nasabah Yang Tepat Dapat Menghindari Kredit Bermasalah di PT. Bank Woori Saudara Indonesia 1906, Tbk.}

Menghindari kredit bermasalah tergantung kepada usaha bank dalam memverifikasi data nasabahnya, serta tergantung kepada itikad baik dari debitur itu sendiri dalam pembayaran kewajiban - kewajiban yang harus dipenuhi kepada pihak bank. Kewajiban itu dapat dalam bentuk pembayaran pokok pinjaman, bunga, denda maupun hal-hal lain yang menjadi beban debitur terhadap pihak bank. Untuk menghindari hal tersebut dibutuhkan verifikasi dokumen yang teliti dan benar agar tidak terjadi kesalahan atau kurangnya informasi tentang debitur tersebut.

Verifikasi data dan dokumen milik debitur yang dilakukan oleh perusahaan adalah dengan cara :

1. Ketika debitur memohon kredit secara on the desk marketing kredit harus dapat menilai kepribadian, karakter dan sikap debitur tersebut. Karena kepribadian, karakter, dan sikap debitur dapat menjadi penilaian Bank apakah debitur tersebut memiliki itikad baik atau tidak dan dapat dipercaya atau tidak. Dari cara bicara debitur kita dapat mengetahui apakah debitur memiliki gejala penyakit seperti darah tinggi atau tidak.

2. Formulir permohonan kredit yang diserahkan oleh debitur harus di cek terlebih dahulu isinya dan harus disesuaikan dengan dokumen yang diserahkan oleh debitur, seperti Kartu Tanda Penduduk (KTP), NPWP, dan dokumen pendukung lainnya.

3. Pengecekan dokumen yang diserahkan oleh debitur kepada pihak atau kantor terkait, seperti pengecekan KTP, NPWP, Surat Nikah, Kartu Keluarga, dan dokumen penting lainnya ke dinas yang sesuai dengan bagian - bagiannya.

4. Bank juga akan menilai agunan atau jaminan yang diserahkan kepada pihak bank dengan syarat $120 \%$ dari plafond yang diberikan kepada debitur. Hal tersebut dilakukan untuk menghitung plafond kredit yang akan diberikan kepada debitur. 
Apabila debitur hanya memberikan Surat Izin Usaha nya, Bank hanya dapat memberikan plafond minim atau menolak pengajuan kredit tersebut karena surat tersebut tidak begitu menguntungkan untuk dijaminkan ke bank. Selain jaminan, Bank akan melihat usaha yang dijalankan oleh debitur apakah berjalan dengan baik atau tidak selama 6 bulan terakhir untuk menilai bahwa debitur tersebut dapat melunasi kewajibannya atau tidak dikemudian hari dengan kondisi usaha nya tersebut.

5. Pihak back office / dokumen bank akan memeriksa terlebih dahulu keaslian data dari debitur tersebut dan melakukan pengecekan Informasi Debitur (iDeb) di Otoritas Jasa Keuangan (OJK) untuk mengetahui apakah debitur memiliki pinjaman kredit di bank lain atau menjadi daftar hitam Bank Indonesia.

6. Jika pengecekan Informasi Debitur Otoritas Jasa Keuangan (iDeb OJK) dinyatakan bersih dan tidak ada masalah pinjaman di bank lain. Jika seluruh dokumen tidak ada yang salah atau kurang, pihak Credit Support akan melakukan pembuatan plafond kredit yang dapat diberikan oleh bank kepada debitur. Lalu rincian plafond pinjaman tersebut akan diserahkan kepada bagian Relationship Officer untuk di informasikan kepada pihak debitur.

7. Apabila debitur menyetujui plafond pinjaman yang diberikan oleh bank dan rincian pembayaran yang harus dilakukan oleh debitur maka pihak Relationship Officer harus meminta persetujuan dan tanda tangan dari Kepala Bagian Kredit dan Pimpinan Cabang (double check).

8. Setelah mendapatkan persetujuan dari Kepala Bagian Kredit dan Pimpinan Cabang dilakukanlah akad kredit sebagai bukti bahwa nasabah menyetujui pinjaman tersebut dan bank menerima agunan yang diserahkan sebagai jaminan oleh debitur.

9. Relationship Officer akan menemui debitur dan meminta foto sebagai bukti bahwa nasabah tersebut benar adanya telah menandatangani perjanjian kredit untuk akad kredit tersebut.

Dengan verifikasi data tersebut, baik melihat karakter debitur dan dokumendokumen yang diberikan debitur kemungkinan kredit bermasalah tersebut masih dapat mungkin terjadi karena kemugkinan usaha nasabah akan mengalami penurunan.

\section{B. Nilai Jaminan Berpengaruh Untuk Membuat Debitur Menghindari Kredit Bermasalah pada perusahaan.}

Jaminan atau agunan di dalam kredit adalah sebuah hal yang diperlukan, karena jika tanpa jaminan yang sesuai bank akan mengalami kerugian yang cukup besar akibat kredit tersebut bermasalah dikemudian hari. Syarat jaminan yang diterima perusahaan adalah wajib minimal bernilai $120 \%$ dari plafond pinjamannya (plafond pinjaman akan diberikan setelah dilakukan penilaian jaminan untuk menghindari kerugian). Apabila debitur tidak memiliki sebuah jaminan yang bernilai minimal $120 \%$ perusahaan akan meminta Surat Izin Usaha dan jaminan tambahan lainnya seperti persediaan, kendaraan, atau harta debitur lainnya untuk mengurangi kerugian apabila kredit tersebut tidak terbayarkan. Tetapi Surat Izin Usaha tersebut akan ditahan di bank sampai kewajiban debitur tersebut selesai. Tentu saja Surat Izin Usaha hanya dapat memberikan plafond kredit minimal karena nilainya yang sangat tidak menguntungkan bank bahkan dapat menimbulkan kerugian kepada pihak bank, oleh karena itu bank jarang sekali menerima jaminan berupa Surat Izin Usaha tanpa adanya jaminan tambahan.

Cara bank mengetahui nilai agunan debitur adalah dengan cara On The Spot Checking dan melakukan taksasi oleh pihak bank. Proses On The Spot Checking dilakukan oleh minimal 2 orang dari pihak bank yaitu bagian Legal dan Credit Investigation atau Credit Support untuk dokumentasi dan untuk penilaian agunan. Untuk pengecekan kebenaran dokumen jaminan berupa tanah, bangunan, dan kendaraan yang diberikan Bank juga bekerjasama dengan lembaga yang berhubungan dengan 
Pengaruh

Verifikasi Data

Nasabah

Kredit UMKM

dan Nilai yang

Diberikan

untuk

Menghindari

Kredit

Bermasalah

\section{7}

jaminan yang dijamin. Contoh untuk pengecekan jaminan berupa bangunan atau tanah secara On The Spot pihak bank akan bertanya kepada warga sekitar untuk kebenaran kepemilikan tanah atau bangunan tersebut lalu pengecekan validasinya dapat di cek ke Badan Pertanahan Nasional (BPN). Karena nilai dari agunan dan jaminan yang diberikan oleh debitur bernilai minimal $120 \%$ diatas plafond pinjaman maka dapat dikatakan hal ini dapat menghindari terjadinya kredit bermasalah. Karena jika debitur tidak melakukan pembayaran dengan baik agunan atau jaminan yang diberikan akan di ambil alih oleh bank untuk di lelang untuk menutupi kerugian akibat kredit tersebut bermasalah. Tetapi jika jaminan tersebut berupa Surat Izin Usaha masih dapat memungkinkan debitur untuk tidak membayar kewajibannya. Dapat dikatakan jika nilai jaminan diatas $120 \%$ dan nilainya bertambah dikemudian hari berpengaruh positif untuk menghindari kredit bermasalah tetapi jika jaminan yang diberikan hanya berupa dokumen seperti (SIUP) dan jaminan tambahan berupa kendaraan dengan nilai dibawah dari syarat bank kemungkinan kredit bermasalah masih dapat terjadi, tetapi dapat dicegah dengan identifikasi karakter nasabah tersebut apakah memiliki kejujuran dan itikad yang baik atau tidak sehingga bank dapat memutuskan debitur ini berhak mendapatkan kredit atau tidak.

\section{Verifikasi Data Nasabah Yang Tepat dan Jenis Jaminan Yang Diberikan Berpengaruh Untuk Menghindari Kredit Bermasalah pada perusahaan}

Setelah dibahas di atas tentang pengaruh verifikasi data debitur yang masih kurang berpengaruh untuk menghindari kredit bermasalah bank juga perlu melihat bentuk jaminan atau agunan yang debitur serahkan. Karena dengan verifikasi dokumen dan data yang tepat serta menilai bentuk jaminan atau agunan yang diberikan dengan tepat cukup efektif untuk mengurangi kredit bermasalah yang terjadi. Karena bank memiliki seluruh dokumen penting dan data yang lengkap dari debitur, mengetahui karakter nasabah dan juga debitur tidak mau mengalami kerugian yang cukup besar karena syarat minimal pinjaman adalah nilai jaminan harus $120 \%$ dari jumlah pinjaman yang diterima. Sehingga debitur merasa harus menyelesaikan kewajibannya dengan baik, kecuali terjadi sesuatu kepada debitur misal saja debitur meninggal ketika kewajibannya belum di lunasi, oleh sebab itu saat akad kredit debitur wajib menggunakan polis asuransi yang harus dibayarkan di awal agar seluruh kewajibannya terlindungi oleh asuransi yang ada jika suatu saat debitur meninggal. Sehingga pihak debitur tidak perlu lagi membayarkan kewajibannya kepada bank karena sudah terlindungi oleh asuransi yang dibayarkan diawal.

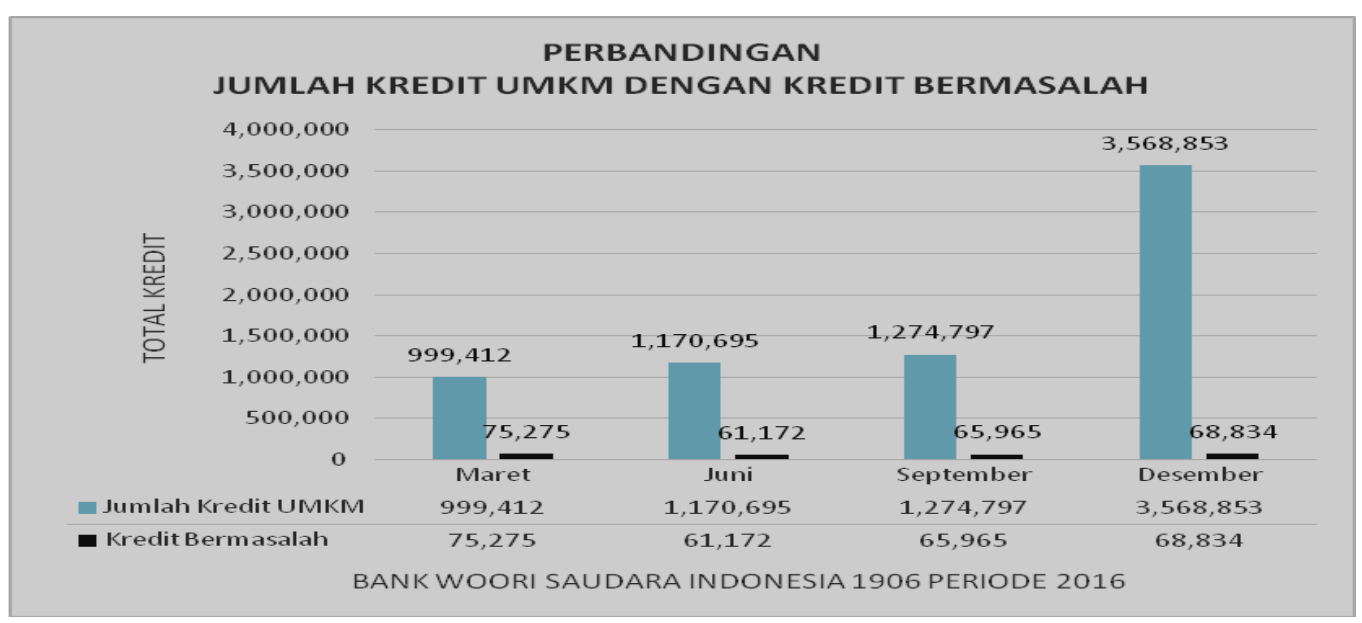

Gambar 1. Perbandingan Total Kredit UMKM Dengan Kredit Bermasalah Bank Woori Saudara 


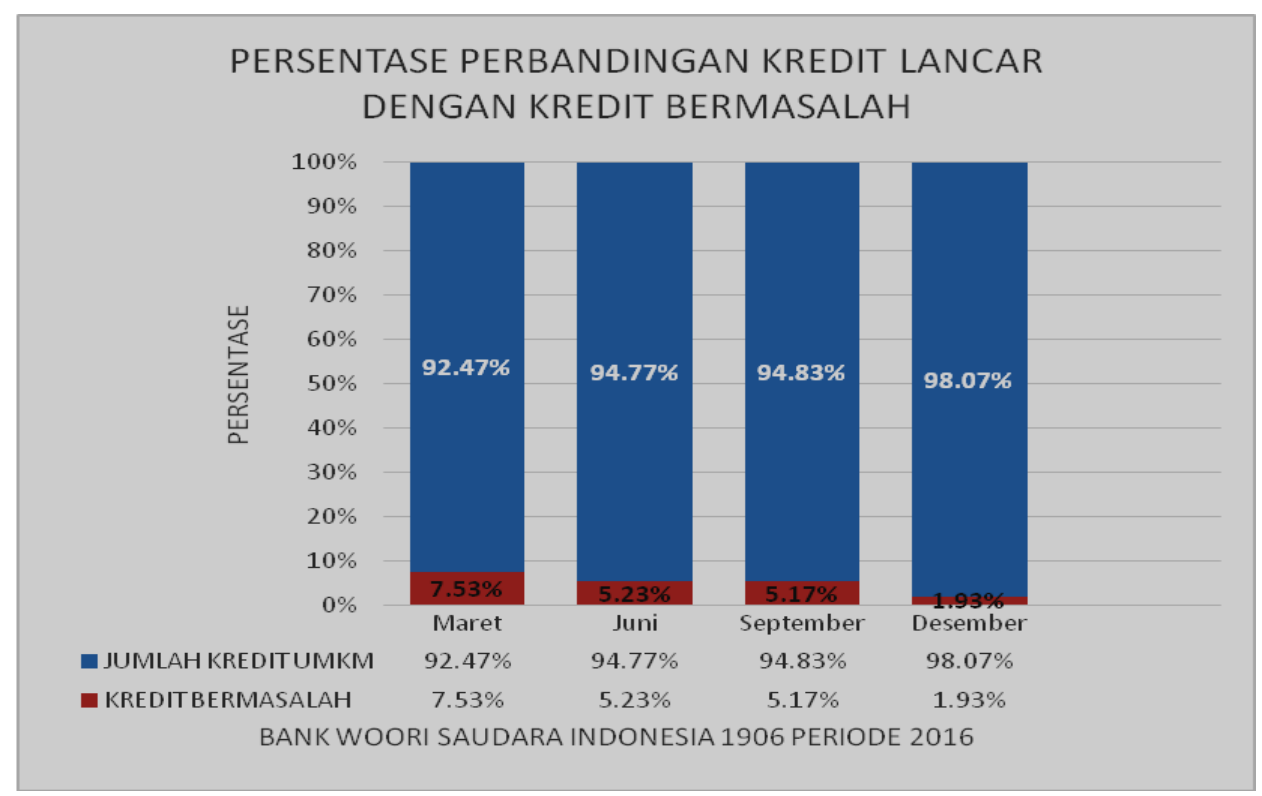

Pengaruh Verifikasi Data Nasabah Kredit UMKM dan Nilai yang Diberikan untuk Menghindari Kredit Bermasalah

Gambar 2.

Persentase Kredit Lancar dan Kredit Bermasalah Bank Woori Saudara Periode 2016

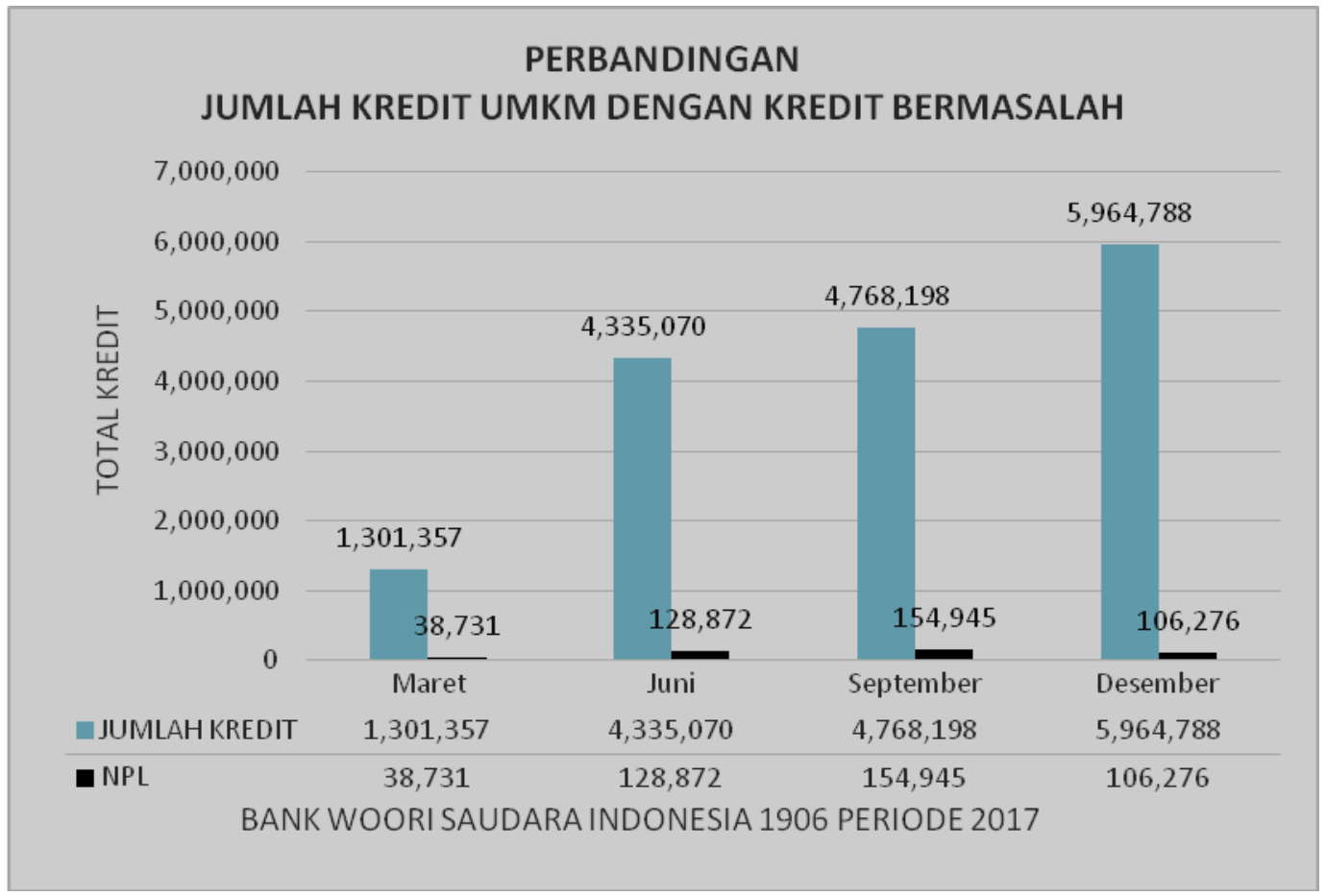

Gambar 3

Perbandingan Total Kredit UMKM Dengan Kredit Bermasalah Bank Woori 
Pengaruh

Verifikasi Data

Nasabah

Kredit UMKM

dan Nilai yang

Diberikan

untuk

Menghindari

Kredit

Bermasalah

239
PERSENTASE PERBANDINGAN KREDIT LANCAR

DENGAN KREDIT BERMASALAH

$100 \%$

$90 \%$

$80 \%$

$70 \%$

晨 $60 \%$

忘 $50 \%$

品 $40 \%$

$30 \%$

$20 \%$
$10 \%$

$0 \%$

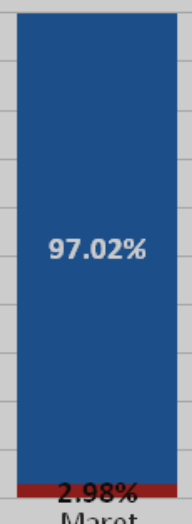

Maret

$97.02 \%$

$2.98 \%$

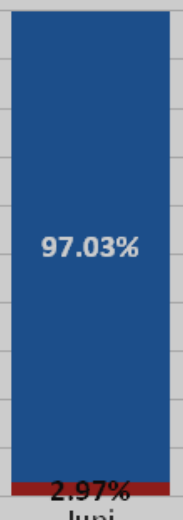

$97.03 \%$

$2.97 \%$

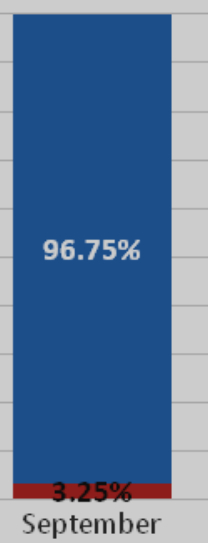

$96.75 \%$

$3.25 \%$

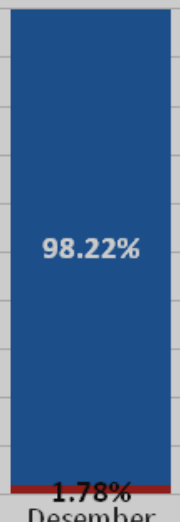

$98.22 \%$

$1.78 \%$

BANK WOORI SAUDARA INDONESIA 1906 PERIODE 2017

Gambar 4.

Persentase Kredit Lancar dan Kredit Bermasalah

Bank Woori Saudara Periode 2017

Pada awal tahun 2016 perusahaan memiliki jumlah kredit bermasalah cukup tinggi karena jumlah kredit yang ada menurun hal ini dapat terjadi karena seasonal (musiman) dan merupakan gejala umum yang sering dirasakan oleh Bank. Tetapi sampai dengan akhir 2016 terjadi penurunan yang cukup signifikan karena prosedur pemberian kredit yang telah dilakukan pihak Bank berfungsi dengan baik meskipun jaminan yang diterima tidak sesuai dengan peningkatan jumlah kreditnya. Walaupun jumlah kredit naik tetapi jumlah kredit bermasalah terlihat menurun. Pada triwulan awal 2017 jumlah kredit bermasalah sangat kecil yaitu 2,98\% walaupun jumlah kredit di atas triwulan awal tahun 2016, ini membuktikan bahwa prosedur pemberian kredit berjalan dengan baik, pada pertengahan 2017 terjadi kenaikan kredit bermasalah karena bertambahnya jumlah kredit yang cukup tinggi. Karena proses restrukturisasi yang dijalankan oleh pihak perusahaan sampai akhir Desember 2017 dan perusahaan mengalami penurunan kredit bermasalah sampai $1,78 \%$ dari sebelumnya 3,25\% dengan jumlah kredit lebih tinggi dari sebelumnya sehingga dapat dikatakan verifikasi data yang tepat dan Nilai jaminan yang diberikan debitur cukup berpengaruh untuk menghindari kredit bermasalah.

Tetapi dilihat pada laporan neraca perusahaan selama periode 2016 dan 2017 untuk jumlah jaminan tidak sesuai dengan jumlah kredit yang diberikan, hal ini terjadi karena kredit yang diberikan lebih banyak kredit unuk usaha mikro dan Bank Woori Saudara Indonesia sering menerima jaminan berupa Surat Izin Usaha dengan jaminan tambahan lainnya. Tetapi walaupun begitu prosedur pemberian kredit yang dijalankan untuk menghindari kredit-kredit bermasalah sudah dilakukan dengan cukup baik sehingga persentase setiap tahun terlihat semakin baik. 
Adapun simpulan dari hasil penelitian ini adalah, sebagai berikut:

1. Bahwa Verifikasi Data Nasabah UMKM sangat penting dilakukan agar tidak sampai terjadi penerimaan nasabah kredit yang memiliki data diri palsu serta dokumen palsu lain agar mendapatkan pinjaman kredit usaha dari bank dan perusahaan telah melakukan prosedur verifikasi data yang cukup baik. Pengecekan BI Checking / iDeb OJK juga diperlukan untuk mengetahui tanggung jawab atau kewajiban debitur yang belum terselesaikan pada bank lain atau lembaga pemberi pinjaman lain. Melihat laporan rekening koran nasabah selama 6 bulan terakhir untuk mengetahui kondisi keuangan debitur, melihat laporan keuangan usaha debitur apakah masih cukup baik atau sering mengalami kerugian. Tetapi jika hanya verifikasi data nasabah kredit saja yang diperiksa dengan teliti dan tepat masih dapat memungkinkan bank mengalami kredit yang bermasalah karena tidak adanya jaminan yang mampu menutupi kerugian bank di kemudian hari.

2. Bahwa jaminan atau agunan yang diberikan sesuai dengan syarat utama bank yaitu minimal $120 \%$ dari plafond kredit yang diterima perusahaan, sehingga sangat cukup mampu menghindari kredit bermasalah dikemudian hari. Karena pihak debitur tidak ingin mengalami kerugian akibat pengambil alihan jaminan, sehingga banyak dari debitur menghindari kredit mereka bermasalah. Tetapi jaminan berupa Surat Izin Usaha dan jaminan tambahan masih dapat mengakibatkan kredit bermasalah meskipun dapat diatasi dengan cara restrukturisasi kredit serta penilaian karakter saat menganalisa debitur tersebut.

3. Bahwa pentingnya verifikasi data nasabah kredit UMKM dan menerima nilai jaminan atau agunan yang tepat sangat mampu mempengaruhi untuk menghindari kredit bermasalah dikarenakan bank dapat menilai debitur tersebut mampu membayar kewajibannya dari analisa dokumen-dokumen yang diterima bank dan debitur tidak mau kehilangan jaminan atau agunan yang diserahkan kepada bank karena nilainya yang lebih tinggi dari plafond yang diberikan, bank mungkin akan mengalami kerugian karena kredit bermasalah tetapi dengan adanya jaminan yang tepat dan sesuai bank tetap dapat mengembalikan dana yang dipinjamkan dengan menjual atau melelang jaminan yang diberikan oleh debitur. Adapun nilai jaminan yang kurang dari persyaratan bank dan bank memberikan kredit tersebut itu dikarenakan penilaian karakter debitur yang baik sehingga bank percaya bahwa debitur tersebut bertanggung jawab atas kewajibannya tersebut.

\section{DAFTAR PUSTAKA}

Gazali, Djoni S, dan Rachmadi Usman 2012. Hukum Perbankan. Jakarta: Sinar Grafika. Undang-Undang Republik Indonesia Nomor 20 Tahun 2008 Tentang Usaha Mikro, Kecil, dan Menengah.

Muhammad Djumhana, 2006. Hukum Perbankan di Indonesia, PT. Citra Aditya Bhakti, Bandung, hlm.231.

Mulyono Teguh Pudjo, 2007. Manajemen Perkreditan Bagi Perbankan. Komersil Yogyakarta.

Peraturan Bank Indonesia No. 5/8/PBI/2003 tentang Penerapan Manajemen Risiko Bagi Bank Umum
Verifikasi Data

Nasabah

Kredit UMKM

dan Nilai yang

Diberikan

untuk

Menghindari

Kredit

Bermasalah

240 